\title{
Impact of increase of caesarean section on postpartum hemorrhage in a tertiary care center of India over 6 years
}

\author{
Shikha Madan ${ }^{1}$, Neetu Sangwan ${ }^{1 *}$, Smiti Nanda $^{1}$, Daya Sirohiwal ${ }^{1}$, \\ Pushpa Dahiya ${ }^{1}$, Savita Singhal ${ }^{1}$, Tarun Arora ${ }^{2}$
}

${ }^{1}$ Department of Obstetrics and Gynaecology, ${ }^{2}$ Department of Community Medicine, PGIMS, Rohtak, Haryana, India

Received: 04 October 2020

Revised: 14 November 2020

Accepted: 17 November 2020

\author{
*Correspondence: \\ Dr. Neetu Sangwan, \\ E-mail: shikhamadan85@gmail.com
}

Copyright: () the author(s), publisher and licensee Medip Academy. This is an open-access article distributed under the terms of the Creative Commons Attribution Non-Commercial License, which permits unrestricted non-commercial use, distribution, and reproduction in any medium, provided the original work is properly cited.

\begin{abstract}
Background: PPH (postpartum hemorrhage) is the leading cause of maternal mortality. Despite of all the medical advancement, maternal mortality rates have declined greatly in the developed world, PPH remains a leading cause of maternal mortality elsewhere. Caesarean section is an obstetric intervention where, normal delivery can pose a risk for mother or foetus. The rate of caesarean section has increased worldwide. A survey conducted by WHO found that the worldwide rate of caesarean section increased from 26.4\% between 2004 to 2008, to 31.2\% between 2010 to 2011 .

Methods: We collected data of the caesarean sections and patients who developed PPH over 6 years. We studied the association of temporal increase of caesarean section with PPH.

Results: Uterine atonicity continues to be the most common etiology of PPH each year, however, there is an increase in tissue abnormality (retained placenta, placenta praevia, accreta, increta, percreta) over years as there is a significant increase in the incidence of caesarean section. Atonic uterus was the most common cause for obstetric hysterectomies and mortality due to PPH every year.

Conclusions: Family planning advise is essential in developing country like ours to counsel patients to prevent multiparity, thus reducing PPH. It is also important to train all the health workers in periphery and referral centers to manage the third stage of labor and atonic uterus to save the mothers. Sagacious attitude towards the decision of caesarean section is needed to prevent maternal morbidity and mortality.
\end{abstract}

Keywords: Caesarean section, Postpartum hemorrhage, Tissue abnormality

\section{INTRODUCTION}

A survey conducted by WHO found that the worldwide rate of caesarean section increased from $26.4 \%$ between 2004 to 2008 , to $31.2 \%$ between 2010 to 2011 . $^{1}$ Despite of a steep decline in the maternal mortality ratio (MMR) in India, the most common direct cause of maternal mortality continues to be the postpartum haemorrhage. ${ }^{2}$ According to the WHO, PPH affects approximately 5\% of all women who give birth. It is not only associated with nearly one quarter of all maternal deaths but also the leading cause of maternal mortality in low income countries. $^{3}$ Caesarean section is an obstetric intervention where normal delivery can pose a risk for mother or foetus. The recommendations by WHO in 1985 were to limit national caesarean section rate to $10-15 \% .^{4}$ This rate however did not take into account the morbidity both fetal and maternal. In 2015, WHO issued a new statement that caesarean section to be provided to the women in need, rather than to achieve any specific rate. ${ }^{5}$ This study was conducted to know the impact of temporal increase of caesarean section on postpartum haemorrhage in a limited resource country.

\section{METHODS}

We conducted a retrospective observational study in Obstetrics and Gynecology department of PGIMS, 
Rohtak from January 2014 to December 2019. All the patients who had PPH were included in the study. They were divided into four groups (G1) those with unscarred uterus, group $2(\mathrm{G} 2)$ those with previous one caesarean section, group $3(\mathrm{G} 3)$ those with previous 2 caesarean section and group $4(\mathrm{G} 4)$ those who have had more than or equal to 3 caesarean section. Each group $\mathrm{G} 1,2,3,4$ was then divided based on the etiology of PPH. Comparisons were made and conclusions drawn on the impact of increased sections on PPH. We have applied one sample $t$ test and paired sample $t$ test on the data. Ethical approval was not taken since it was a retrograde observational study.

\section{RESULTS}

The demographic profile of patients from 2014 to 2019 were comparable. The patients who had PPH were divided into gravida 1 , gravida 2 , gravida 3 , gravida 4 and above. It was observed that most of the patients who had PPH were either gravida 3 or more than or equal to gravida 4 . This observation was same in all 6 years.

Table 1: Distribution of normal vaginal deliveries and caesarean section over 6 years.

\begin{tabular}{|lllll|}
\hline Year & $\begin{array}{l}\text { Normal } \\
\text { vaginal } \\
\text { deliveries }\end{array}$ & $\begin{array}{l}\text { Caesarean } \\
\text { sections }\end{array}$ & Total & $\begin{array}{l}\text { Increase \% of } \\
\text { total deliveries } \\
\text { each year }\end{array}$ \\
\hline $\mathbf{2 0 1 4}$ & $\begin{array}{l}7324 \\
(75.09 \%)\end{array}$ & $\begin{array}{l}2430 \\
(24.91 \%)\end{array}$ & 9754 & - \\
\hline $\mathbf{2 0 1 5}$ & $\begin{array}{l}7489 \\
(74.98 \%)\end{array}$ & $\begin{array}{l}2500 \\
(25.02 \%)\end{array}$ & 9989 & $2.35 \%$ \\
\hline $\mathbf{2 0 1 6}$ & $\begin{array}{l}7789 \\
(73.99 \%)\end{array}$ & $\begin{array}{l}2739 \\
(26.01 \%)\end{array}$ & 10528 & $5.1 \%$ \\
\hline $\mathbf{2 0 1 7}$ & $\begin{array}{l}7944 \\
(70.64 \%)\end{array}$ & $\begin{array}{l}3302 \\
(29.36 \%)\end{array}$ & 11246 & $6.38 \%$ \\
\hline $\mathbf{2 0 1 8}$ & $\begin{array}{l}8355 \\
(71.65 \%)\end{array}$ & $\begin{array}{l}3306 \\
(28.35 \%)\end{array}$ & 11661 & $3.5 \%$ \\
\hline $\mathbf{2 0 1 9}$ & $\begin{array}{l}9630 \\
(72.13 \%)\end{array}$ & $\begin{array}{l}3722 \\
(27.87 \%)\end{array}$ & 13352 & $12.6 \%$ \\
\hline
\end{tabular}

The age of the patients was divided into less than 18 years, 18-23 years, 24-29 years, 30-35 years, and more than 35 years. Majority of patients who had PPH were in the age group of 24-29 years and 30-35 years. This is common because by the time female becomes multi gravida, she is in this age group range. This pattern has been comparable over 6 years.

Table 2: Distribution of patients with PPH in 4 groups (G1 unscarred uterus, G2 previous 1 caesarean section, G3 previous 2 caesarean section, $\mathbf{G} 3$ equal to or more than previous 3 caesarean section).

\begin{tabular}{|llllll|}
\hline Year & $\begin{array}{l}\text { Total } \\
\text { PPH }\end{array}$ & G1 & G2 & G3 & G4 \\
\hline 2014 & 327 & $\begin{array}{l}236 \\
(72.17 \%)\end{array}$ & $\begin{array}{l}89 \\
(27.21 \%)\end{array}$ & $\begin{array}{l}2 \\
(0.62 \%)\end{array}$ & $0(0 \%)$ \\
\hline $\mathbf{2 0 1 5}$ & 330 & $\begin{array}{l}217 \\
(65.75 \%)\end{array}$ & $\begin{array}{l}108 \\
(32.72 \%)\end{array}$ & $\begin{array}{l}(1.21 \%) \\
1(0.32 \%)\end{array}$ \\
\hline $\mathbf{2 0 1 6}$ & \multirow{2}{*}{348} & $\begin{array}{l}210 \\
(60.34 \%)\end{array}$ & $\begin{array}{l}127 \\
(36.49 \%)\end{array}$ & $\begin{array}{l}10 \\
(2.87 \%)\end{array}$ & $1(0.3 \%)$ \\
\hline $\mathbf{2 0 1 7}$ & \multirow{2}{*}{390} & $\begin{array}{l}266 \\
(68.20 \%)\end{array}$ & $\begin{array}{l}116 \\
(29.74 \%)\end{array}$ & $\begin{array}{l}8 \\
(2.05 \%)\end{array}$ & $0(0 \%)$ \\
\hline $\mathbf{2 0 1 8}$ & 327 & $\begin{array}{l}216 \\
(66.05 \%)\end{array}$ & $\begin{array}{l}96 \\
(29.35 \%)\end{array}$ & $\begin{array}{l}15 \\
(4.59 \%)\end{array}$ & $0(0 \%)$ \\
\hline $\mathbf{2 0 1 9}$ & 319 & $196(61.44)$ & $\begin{array}{l}111 \\
(34.79 \%)\end{array}$ & $\begin{array}{l}11 \\
(3.44 \%)\end{array}$ & $1(0.31 \%)$ \\
\hline
\end{tabular}

The total number of vaginal deliveries and caesarean sections in 2014 were 9754, in 2015 were 9989, in 2016 were 10528, in 2017 were 11246, in 2018 were 11661 and in 2019 were 13352.

From Table 1 it can be observed that the total number of normal deliveries and the total number of caesarean sections have increased over 6 years, from being 9754 in 2014 to 13352 in 2019. There has been an increase in delivery percentage each year. By one sample $t$ test the increase in normal delivery and caesarean section were both significant $(\mathrm{p}<0.05)$. By the paired sample t test we found that though there was an increase in both normal vaginal deliveries and caesarean section, but the increase in normal vaginal delivery was more significantly increased than caesarean sections $(\mathrm{p}<0.05)$. This increase is attributed to both increase in population and increase in the incidence of institutional deliveries. The average caesarean section of our institute in 6 years was $26.92 \%$. This high rate of caesarean section was because ours is the prime referral centre in the state and also in adjoining areas.

Table 3: Etiology of PPH.

\begin{tabular}{|llllll|}
\hline Year & Total & Atonic & Traumatic & Tissue abnormality & Coagulation abnormality \\
\hline $\mathbf{2 0 1 4}$ & 327 & $229(70.03 \%)$ & $73(22.32 \%)$ & $19(5.81 \%)$ & $6(1.83 \%)$ \\
\hline $\mathbf{2 0 1 5}$ & 330 & $229(69.39 \%)$ & $76(23.03 \%)$ & $19(5.75 \%)$ & $6(1.81 \%)$ \\
\hline $\mathbf{2 0 1 6}$ & 348 & $206(59.19 \%)$ & $98(28.16 \%)$ & $34(9.7 \%)$ & $10(2.8 \%)$ \\
\hline $\mathbf{2 0 1 7}$ & 390 & $263(67.43 \%)$ & $67(17.17 \%)$ & $54(13.84 \%)$ & $6(1.5 \%)$ \\
\hline $\mathbf{2 0 1 8}$ & 327 & $198(60.55 \%)$ & $73(22.32 \%)$ & $50(15.29 \%)$ & $6(1.83 \%)$ \\
\hline $\mathbf{2 0 1 9}$ & 319 & $196(61.44 \%)$ & $76(23.82 \%)$ & $43(13.47 \%)$ & $4(1.25 \%)$ \\
\hline Total & 2041 & $1321(64.72 \%)$ & $463(22.68 \%)$ & $219(10.73 \%)$ & $38(1.86 \%)$ \\
\hline
\end{tabular}


The total number of patients who had PPH in 2014, 2015, 2016, 2017, 2018 and 2019 was 327, 330, 348, 390, 327 and 319 respectively. These patients were divided into four groups (G1) those with unscarred uterus, group 2 (G2) those with previous one caesarean section, group 3 (G3) those with previous 2 caesarean section and group 4 (G4) those who have had more than or equal to 3 caesarean section.

From Table 2 it can be clearly seen that the most common group to have PPH was G1 with unscarred uterus, followed by $\mathrm{G} 2$ with previous one caesarean section. This pattern was common in all 6 years. It was also observed that the percentage of patients having $\mathrm{PPH}$ in $\mathrm{G} 3$ (those with previous 2 caesarean section) increased from $1.21 \%$ in 2015 to $2.87 \%$ in 2016 .
In 6 years, patients with unscarred uterus had incidence of $\mathrm{PPH}$ of $2.03 \%$, whereas, those with previous caesarean section had incidence of $3.03 \%$.

The etiology of PPH was divided into atonic, traumatic, tissue abnormality (retained placenta, placenta previa, accrete, increta and percreta) and coagulation abnormality.

From Table 3, it can be seen that the most common cause of $\mathrm{PPH}$ continues to be atonic uterus, however the percentage of atonic uterus declined from $70.03 \%$ to $61.44 \%$ over 6 years. This drop has occurred due to the strategy adopted in LR to assure administration of uterotonics immediately after birth of baby.

Table 4: Distribution of patients in G1 (unscarred uterus).

\begin{tabular}{|llllll|}
\hline Year & Total patients G1 & Atonic uterus & Traumatic & Tissue abnormality & Coagulation abnormality \\
\hline $\mathbf{2 0 1 4}$ & 236 & 188 & 43 & 2 & 3 \\
\hline $\mathbf{2 0 1 5}$ & 217 & 168 & 39 & 4 & 6 \\
\hline $\mathbf{2 0 1 6}$ & 210 & 143 & 55 & 5 & 7 \\
\hline $\mathbf{2 0 1 7}$ & 266 & 205 & 38 & 18 & 5 \\
\hline $\mathbf{2 0 1 8}$ & 216 & 134 & 52 & 26 & 4 \\
\hline $\mathbf{2 0 1 9}$ & 196 & 114 & 51 & 28 & 3 \\
\hline Total & 1341 & $952(70.99 \%)$ & $278(20.73 \%)$ & $83(6.19 \%)$ & $28(2.09 \%)$ \\
\hline
\end{tabular}

Table 5: Distribution of patients in G2 (previous one caesarean section).

\begin{tabular}{|llllll|}
\hline Year & Total patients G2 & Atonic uterus & Traumatic & Tissue abnormality & Coagulation abnormality \\
\hline $\mathbf{2 0 1 4}$ & 89 & 41 & 29 & 16 & 3 \\
\hline $\mathbf{2 0 1 5}$ & 108 & 61 & 36 & 11 & 0 \\
\hline $\mathbf{2 0 1 6}$ & 127 & 61 & 41 & 22 & 3 \\
\hline $\mathbf{2 0 1 7}$ & 116 & 54 & 27 & 34 & 1 \\
\hline $\mathbf{2 0 1 8}$ & 96 & 57 & 15 & 22 & 2 \\
\hline $\mathbf{2 0 1 9}$ & 111 & 77 & 21 & 13 & 0 \\
\hline Total & 647 & $351(54.25 \%)$ & $169(26.12 \%)$ & $118(18.23 \%)$ & $9(1.40 \%)$ \\
\hline
\end{tabular}

Table 6: Distribution of patients in G3 (previous two caesarean section).

\begin{tabular}{|llllll|}
\hline Year & Total patients G3 & Atonic uterus & Traumatic & Tissue abnormality & Coagulation abnormality \\
\hline $\mathbf{2 0 1 4}$ & 2 & 0 & 1 & 1 & 0 \\
\hline $\mathbf{2 0 1 5}$ & 4 & 0 & 1 & 3 & 0 \\
\hline $\mathbf{2 0 1 6}$ & 10 & 2 & 2 & 6 & 0 \\
\hline $\mathbf{2 0 1 7}$ & 8 & 4 & 2 & 2 & 0 \\
\hline $\mathbf{2 0 1 8}$ & 15 & 7 & 6 & 2 & 0 \\
\hline $\mathbf{2 0 1 9}$ & 11 & 5 & 3 & 2 & 1 \\
\hline Total & 50 & $18(36 \%)$ & $15(30 \%)$ & $16(32 \%)$ & $1(2 \%)$ \\
\hline
\end{tabular}

From Table 2 it can be seen that PPH is more commonly seen in unscarred uterus and Table 3 shows that the most common etiology is atonic uterus over 6 years. It was seen that the patients who are gravida 3 or more than or equal to gravida 4 had higher number of PPH. This pattern clearly indicates that multigravida patients are more prone to have PPH due to atonic uterus than those who have underwent previous caesarean section, this is because caesarean section patients are duly counselled and they are more motivated for tubal ligation during caesarean sections.

Another observation from Table 3 was that there was an increase in the number of tissue abnormality (retained 
placenta, placenta praevia, accrete, increta, percreta). This was $5.81 \%$ in 2014 which increased to $13.84 \%$ in 2017 and was $13.47 \%$ in 2019. This increase in tissue abnormality was because of the increase in caesarean section rates from 2014 to 2019. However, our institute advocates TOLAC (trial of labour after caesarean section) and maintains an audit on the indications of sections to keep this number under scrutiny.

Table 7: Distribution of patients in G4 (previous 3 or more caesarean section).

\begin{tabular}{|llllll|}
\hline Year & Total patients G4 & Atonic uterus & Traumatic & $\begin{array}{l}\text { Tissue } \\
\text { abnormality }\end{array}$ & $\begin{array}{l}\text { Coagulation } \\
\text { abnormality }\end{array}$ \\
\hline $\mathbf{2 0 1 4}$ & 0 & 0 & 0 & 0 & 0 \\
\hline $\mathbf{2 0 1 5}$ & 1 & 0 & 0 & 1 & 0 \\
\hline $\mathbf{2 0 1 6}$ & 1 & 0 & 0 & 1 & 0 \\
\hline $\mathbf{2 0 1 7}$ & 0 & 0 & 0 & 0 & 0 \\
\hline $\mathbf{2 0 1 8}$ & 0 & 0 & 0 & 0 & 0 \\
\hline $\mathbf{2 0 1 9}$ & 1 & 0 & 1 & 0 & 0 \\
\hline Total & 3 & 0 & $1(33.33 \%)$ & $2(66.66 \%)$ & 0 \\
\hline
\end{tabular}

Table 8: Total number of hysterectomy due to PPH over 6 years.

\begin{tabular}{|lllll|}
\hline Year & Atonic & Traumatic & Tissue abnormality & Total \\
\hline $\mathbf{2 0 1 4}$ & 7 & 3 & 1 & 11 \\
\hline $\mathbf{2 0 1 5}$ & 8 & 3 & 2 & 13 \\
\hline $\mathbf{2 0 1 6}$ & 8 & 2 & 10 & 20 \\
\hline $\mathbf{2 0 1 7}$ & 6 & 1 & 9 & 16 \\
\hline $\mathbf{2 0 1 8}$ & 4 & 4 & 7 & 15 \\
\hline $\mathbf{2 0 1 9}$ & 13 & 2 & 6 & 21 \\
\hline Total & $46(47.91 \%)$ & $15(15.62 \%)$ & $35(36.4 \%)$ & 96 \\
\hline
\end{tabular}

From Tables 4, 5, 6, and 7, it can be seen that atonic uterus was the most common etiology in G1 (unscarred uterus), G2 (previous one caesarean section), G3 (previous two caesarean section), this was followed by traumatic uterus in G1 and G2. However, in G4 (more than or equal to previous three caesarean sections) tissue abnormality was the most common etiology and second common cause in G3. Also, when we compared the tissue abnormality (retained placenta, placenta previa, placenta accreta, increta, percreta) in all the groups (Figure 1), we found that there was an increasing trend with the increase in number of caesarean sections.

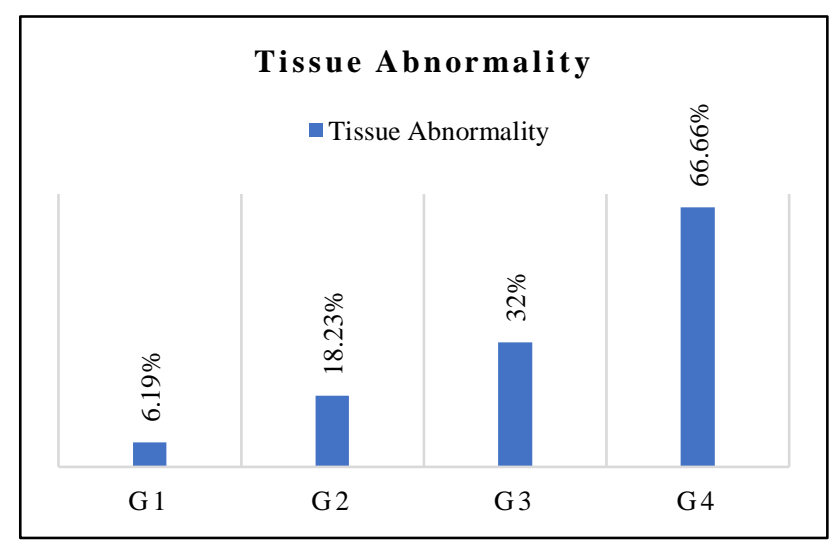

Figure 1: Comparison of tissue abnormality in G1, G2, G3 and G4.
The total hysterectomies due to PPH over 6 years was 96 . The most common etiology of PPH was atonic uterus, followed by tissue abnormality and then traumatic cause.

From Table 8 it can be seen that the number of hysterectomies increased in 2016 and 2019. In 2016, the number of hysterectomies increased due to tissue abnormality (retained placenta, placenta praevia, accreta, percreta, increta), whereas in 2019, the most common cause of hysterectomies was atonic uterus. Over all in 6 years atonic uterus was the most common reason for hysterectomy due to PPH.

The overall mortality rate due to PPH over 6 years was $2.54 \%$.

Table 9: Mortality due to PPH.

\begin{tabular}{|llll|}
\hline Year & $\begin{array}{l}\text { No. of mortality } \\
\text { due to PPH }\end{array}$ & Total PPH & Percentage \\
\hline $\mathbf{2 0 1 4}$ & 6 & 327 & 1.83 \\
\hline $\mathbf{2 0 1 5}$ & 10 & 330 & 3.03 \\
\hline $\mathbf{2 0 1 6}$ & 8 & 348 & 2.29 \\
\hline $\mathbf{2 0 1 7}$ & 8 & 390 & 2.05 \\
\hline $\mathbf{2 0 1 8}$ & 11 & 327 & 3.36 \\
\hline $\mathbf{2 0 1 9}$ & 9 & 319 & 2.82 \\
\hline Total & 52 & 2041 & 2.54 \\
\hline
\end{tabular}


From Table 9, it can be seen that the mortality due to $\mathrm{PPH}$ ranges from as low as $1.83 \%$ in 2014 to highest $3.36 \%$ in 2018 . The impact of caesarean section on mortality due to PPH was compared between the 4 groups (Table 10).

Table 10: Comparison of mortality between G1, G2, G3 and G4.

\begin{tabular}{|llllll|}
\hline Year & $\begin{array}{l}\text { Total } \\
\text { mortality }\end{array}$ & G1 & G2 & G3 & G4 \\
\hline $\mathbf{2 0 1 4}$ & 6 & 4 & 1 & 1 & 0 \\
\hline $\mathbf{2 0 1 5}$ & 10 & 7 & 2 & 1 & 0 \\
\hline $\mathbf{2 0 1 6}$ & 8 & 5 & 2 & 1 & 0 \\
\hline $\mathbf{2 0 1 7}$ & 8 & 7 & 0 & 1 & 0 \\
\hline $\mathbf{2 0 1 8}$ & 11 & 7 & 3 & 1 & 0 \\
\hline $\mathbf{2 0 1 9}$ & 9 & 7 & 2 & 0 & 0 \\
\hline Total & 52 & 37 & 10 & 5 & 0 \\
\hline
\end{tabular}

From Table 10, it can be seen that the mortality rate was highest in G1 group, this was found because atonic uterus was the most common etiology and atonic uterus was commonly present in multiparous patients. Doing a caesarean section gives an opportunity to do tubal ligation and prevents further pregnancies. However, the mortality in G2 and G3 cannot be ignored, these groups also had mortalities due to complications of previous caesarean sections like placenta accreta, increta and percreta. Hence, a continuous scrutiny and a wiser approach of making an indication of caesarean is needed.

\section{DISCUSSION}

India is the second most populated country in the world with nearly a fifth of the world's population. According to the 2019 revision of the world population prospects population stood at $1,352,642,280 .^{6,7}$ India's population growth rate is $1.13 \% .^{8}$ One of the major causes of maternal mortality in India continues to be PPH. We collected data over 6 years in our institute. When the demographic profiles of the patients were compared, majority of patients who had PPH were in the age group of 24-29 years and 30-35 years. This age group is common in India because when a female in reproductive age group reaches this age, she is multigravida. This correlation has been found in other studies as well. ${ }^{9}$ There has been an exponential increase in the percentage of delivery annually in our institute from $2.35 \%$ from 2014 to 2015 to $12.6 \%$ from 2018 to 2019 . This increase in the percentage of delivery is because of the expanding population of the country and also due to increasing number of hospital deliveries due to more education and awareness. The average growth rate of population in India is $1.13 \% .^{8}$ Over a period of 6 years, 66,530 patients delivered in our institute both by normal vaginal delivery and by caesarean section. Out of these 2041 patients (3.06\%) had PPH. In 2014, 2015, 2016, 2017, 2018 and 2019 the percentage of women who delivered and had
PPH were $3.35 \%$ (327), $3.30 \%$ (330), $3.30 \%$ (348), $3.46 \%$ (390), $2.80 \%$ (327) and $2.38 \%$ (319) respectively. Devi et al also found a similar result that postpartum hemorrhage (PPH) is a frequent complication of delivery and its incidence is commonly reported as $2-4 \%$ after vaginal delivery and $6 \%$ after caesarean section with uterine atony being the cause in about $50 \%$ cases. ${ }^{10}$ In 6 years patients with unscarred uterus had incidence of PPH of $2.03 \%$, whereas, those with previous caesarean section had incidence of $3.03 \%$. Also, we found that overall, the most common cause of PPH continues to be atonic uterus, however the percentage of atonic uterus declined from $70.03 \%$ to $61.44 \%$ over 6 years. The multigravida patients are more prone to have $\mathrm{PPH}$ due to atonic uterus than those who have underwent previous caesarean section, this is because caesarean section patients are duly counselled and they are more motivated for tubal ligation during caesarean sections. There are studies which also have the same findings of multigravida as a risk factor for PPH. ${ }^{11,12}$ Atonic uterus was the most common etiology in patients with unscarred uterus, previous one caesarean section, previous two caesarean section, this was followed by traumatic uterus in patients with unscarred uterus and patients with previous one caesarean section. However, in patients with more than or equal to previous three caesarean sections tissue abnormality was the most common etiology and second common cause in patients with previous two caesarean sections. Also, when we compared the tissue abnormality (retained placenta, placenta previa, placenta accreta, increta, percreta) in all the groups, we found that there was an increasing trend with the increase in number of caesarean sections from $6.19 \%$ in patients with unscarred uterus to $66.66 \%$ in patients with more than or equal to previous 3 caesarean sections. There are studies which have found an increase in placenta accreta with increase in caesarean sections. For women with placenta previa, the risk of placenta accreta is $3 \%, 11 \%, 40 \%, 61 \%$, and $67 \%$, for the first, second, third, fourth, and fifth or more cesarean, respectively. ${ }^{13}$ The mortality rate of $\mathrm{PPH}$ is highest due to atonic uterus, most commonly in multiparous patients, however the mortality rates in patients with previous caesarean section complications with PPH cannot be ignored. These results strongly suggest the need of active management of atonic uterus and a contemplative decision of caesarean sections.

\section{CONCLUSION}

We studied the data of PPH of 6 years in our institute, and observed certain trends. The total number of vaginal deliveries and caesarean section have significantly increased each year. Uterine atonicity continues to be the most common etiology of PPH every year, however, there is an increase in tissue abnormality (retained placenta, placenta praevia, accreta, increta, percreta) over years as there is a significant increase in the incidence of caesarean section. Atonic uterus was the most common cause for obstetric hysterectomies and mortality due to $\mathrm{PPH}$ every year. Family planning advise is essential in 
developing country like ours to counsel patients to prevent multiparity, thus reducing $\mathrm{PPH}$. It is also important to train all the health workers in periphery and referral centers to manage the third stage of labour and atonic uterus to save the mothers. Sagacious attitude towards the decision of caesarean section is needed to prevent maternal morbidity and mortality.

Funding: No funding sources

Conflict of interest: None declared

Ethical approval: The study was approved by the Institutional Ethics Committee

\section{REFERENCES}

1. Vogel JP, Betrán AP, Vindevoghel N, Souza JP, Torloni MR, Zhang J, et al. WHO Multi-Country Survey on Maternal and Newborn Health Research Network. Use of the Robson classification to assess caesarean section trends in 21 countries: a secondary analysis of two WHO multicountry surveys. Lancet Glob Health. 2015;3(05):e260-70.

2. Special Bulletin of Maternal Mortality in India 201618. Office Of The Registrar General, India. Available from: https://censusindia.gov.in/ vital_statistics/SRS_Bulletins/MMR\%20Bulletin\%2 02016-18.pdf

3. Vogel JP, Williams M, Gallos I, Althabe F, Oladapo OT.. WHO recommendations on uterotonics for postpartum haemorrhage prevention: what works, and which one? BMJ Glob Health. 2019;4:e001466.

4. B Chalmers. Appropriate technology for birth. Br J Obstet Gynaecol. 1992;99(9):709-10.

5. World Health Organization. WHO statement on caesarean section rates. Geneva: World Health Organization; 2015. Available from: https://www.who.int/reproductivehealth/publications /maternal_perinatal_health/cs-statement/en/.

6. World Population prospects- Population division. United Nations Department of Economic and Social
Affairs, Population Division. Available from: https://population.un.org/wpp/. Accessed on 9 November 2019.

7. Overall total population- World Population Prospects: The 2019 Revision. population.un.org (custom data acquired via website). United Nations Department of Economic and Social Affairs, Population Division. Retrieved 9 November 2019.

8. Population growth (annual \%) World Bank. Retrieved 20 January 2015. Available from: https://data.worldbank.org/indicator/SP.POP.GROW .

9. Rajeshwari, Sreelatha S, Shruthi K, Kumar S, Shruthi A, Malpurae P. A study on risk factors of postpartum hemorrhage. New Indian J OBGYN. 2020;6(2):83-6.

10. Devi KP, Singh LR, Singh LB, Singh MR, Singh NN. Postpartum hemorrhage and maternal deaths in North East India. Open J of Obstet Gynaecol. 2015;5:635-8.

11. Kramer MS, Berg C, Abenhaim H, Dahhou M, Rouleau J, Mehrabadi A, et al. Incidence, risk factors, and temporal trends in severe postpartum hemorrhage. Am J Obstet Gynecol. 2013;209:449e17.

12. Sosa CG, Althabe F, Belizan JM, Buekens P. Risk factors for postpartum hemorrhage in vaginal deliveries in a Latin-American population. Obstet Gynecol 2009; 113:1313-9.

13. Silver RM, Landon MB, Rouse DJ, Leveno KJ, Spong CY, Thom EA, et al. Maternal morbidity associated with multiple repeat cesarean deliveries. National Institute of Child Health and Human Development Maternal-Fetal Medicine Units Network. Obstet Gynecol. 2006;107:1226-32.

Cite this article as: Madan S, Sangwan N, Nanda S, Sirohiwal D, Dahiya P, Singhal S, et al. Impact of increase of caesarean section on postpartum hemorrhage in a tertiary care center of India over 6 years. Int J Reprod Contracept Obstet Gynecol 2021;10:192-7. 